\title{
Analysis of the Implementation of Anti Money Laundering and Terrorism Funding Prevention Programs in PT Asuransi Jiwa X
}

\author{
Ezra Situmeang*, Jan Hoesada* \\ Magister of Accounting, Mercu Buana University, J1. Meruya Selatan No.1, West Jakarta, Jakarta 11650, Indonesia
}

DOI: $10.36348 / \mathrm{sb} .2019 . \mathrm{v} 05 \mathrm{i} 11.003$

| Received: 04.08.2019 | Accepted: 23.08.2019 | Published: 09.11.2019

*Corresponding author: Ezra Situmeang and Jan Hoesada

\section{Abstract}

Money laundering is a phenomenon which undermines the country's economy and political stability. This phenomenon is a national and international concern. Put simply, this practice is the conversion of black money into white money. If done successfully, it will allow the perpetrators to maintain control of their results and ultimately provide legal protection for the sources of income of the perpetrators. Money laundering is playing a crime money to facilitate the ambitions of smugglers and terrorists. This research uses quantitative methods with descriptive analysis and primary data. The results of this study are that PT Asuransi Jiwa X already has and implements policies and procedures, Supervision conducted by the Board of Directors has been very effective and the company has a special work unit, has monitored and updated customers, reporting STR, has a list of terrorists and all employees new and existing ones have attended AML and CTF training and have been carried out by requesting information and supporting documents for prospective customers.

Keywords: Money Laundering, Prevention of Terrorism, Quantitative, Descriptive Research, Primary Data.

Copyright @ 2019: This is an open-access article distributed under the terms of the Creative Commons Attribution license which permits unrestricted use, distribution, and reproduction in any medium for non-commercial use (NonCommercial, or CC-BY-NC) provided the original author and source are credited.

\section{INTRODUCTION}

With advances in financial services such as insurance, banks, and other techniques used by money launderers to launder money is increasing. Money laundering and terrorism financing have a negative impact on the stability of the country's economy and have a serious threat to the social economy and government. In general, insurance is considered as an important source of valuable information for detecting money laundering. However, from an Insurance perspective their main reason is to get as much profit as possible. In 2012, Indonesia was included in the FATF (Financial Action Task Force) blacklist because it was deemed unwilling to help in eradicating financial transactions that were against the law and in 2015 Indonesia was freed from the FATF blacklist. FATF agrees to Indonesia's membership because Indonesia's progress is very significant because it has Law No. 8 of 2010 concerning the Prevention and Eradication of Criminal Acts on Financing Terrorism, and issuing joint regulations regarding the proliferation of weapons of mass destruction. Juridically fighting against money laundering begins with Law No. 15 of 2002, Law No. 25 of 2003 and Law No. 8 of 2010. PPATK is an independent institution that is given the task and authority to combat money laundering in
Indonesia. Financial service providers are required to implement the five pillars. The application process starts at the time of opening the policy, monitoring transactions and closing the policy by carrying out the stages of conducting customer due diligence, further due diligence, risk-based approach, and reporting suspicious financial transactions.

\section{LITERATURE REVIEW Agency Theory}

According to Jensen and Meckling [1] in Ujiyantho \& Scout [2] explains that agency relationship as a contract where one or more (principal) hires another person (agent) to perform some services for their interests by delegating some decision making authority to the agent.

\section{Internal Control}

According to ISA 315 Paragraph $4 \mathrm{c}$ in Theodorus [3]: Internal Control is a process that is designed, implemented and maintained by management and other employees to provide adequate assurance about the achievement of entity objectives regarding financial reporting constraints, effective and efficient operation, and compliance with laws and regulations 
per law.

\section{Money Laundering}

In SEOJK No. 37 / SEOJK.05 / 2017 dated 17 July 2017 [4] concerning Guidelines for Implementing Anti-Money Laundering and Prevention of Terrorism Funding Programs in the Non-Bank Financial Industry Sector defines money laundering as an act of placing, transferring, paying, spending, granting, donating, depositing, bringing to foreign exchange, exchange, or other acts of assets that are known or reasonably suspected of being the result of a criminal act with the intent to conceal or disguise the origin of assets so that they appear to be legitimate assets.

\section{Stages of Money Laundering}

There are three stages in the process of money laundering, namely placement, layering, and integration.

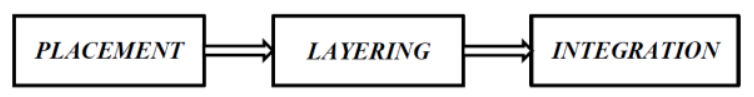

Fig-1: Illustration of Money Laundering Stages

\section{Terrorism Funding}

Criminal Funding for Terrorism is the use of assets directly or indirectly for terrorism activities, terrorist or terrorist organizations. Funding terrorism is basically a different type of crime from Money Laundering, however both of them contain similarities, namely using financial services as a means to commit a crime.

\section{METHODOLOGY}

The object of research is the Application of Money Laundering and Prevention of Funding at PT Asuransi Jiwa $X$. The researcher cannot reveal the name of the organization because the researcher and the party that is the subject of the matter to be investigated have made an agreement and it is related to the confidentiality of the data.

This research uses quantitative methods with descriptive analysis. The data used are primary data. The research was taken by conducting interviews with internal supervisors and company managers and collecting documents related to this research.

In this study, researchers used critical case sampling because the case discussed in this study was a critical matter that had advantages and disadvantages that would be revealed by the researcher and based on the researcher's experience.

The research sample consisted of 3 people with the criteria that the informants understand and have knowledge about the application of these regulations.

As for the sources in this study, the Internal Supervisor has the responsibility to carry out the internal audit function, the AML and CTF Managers have the responsibility of making the AML and CTF reports and the Chief Operating Officer with the first line of analysis.

\section{Data Collection}

Collecting documents related to the object of this study, and interviews with the resource persons who are the objects in this study.

\section{Data Analysis}

Based on the data obtained, will be analyzed in order to know the data that will be used and useful for research.

\section{The results of the study will be compared with the} Regulations

The results of the data analysis will be compared with the theory obtained.

\section{Give Conclusions and Recomendations}

The final step is to provide conclusions and advice to PT Asuransi Jiwa X if there are deficiencies in the implementation of AML and CTF.

\section{RESULTS AND DISCUSSION \\ Mechanism Analysis}

Based on interviews PT Asuransi Jiwa X has carried out monitoring and updates in accordance with POJK number 12 of 2017, there have been officers assigned to monitor transactions whose values are suspicious and do not match the customer's profile. The officer has screened by making a customer profile documentation that includes monthly income of prospective customers. If you find a case that leads to money laundering, an investigation will be carried out related to where the source of funds came from. If the investigation shows that the customer is suspicious or will be made a STR. Monitoring of terrorist funding of PT Asuransi Jiwa X has made a list issued by the Police.

In the AML and CTF program employees must get a briefing and understanding of the AML and CTF program. PT Asuransi Jiwa X has provided AML and CTF training for new and existing employees.

But what needs to be considered in the AML and CTF mechanism PT Asuransi Jiwa X has not yet 
conducted a special audit of AML and CTF. So far, what has been done is functional audit because AML and CTF are under the Compliance function, so when auditing the Compliance function, including AML and CTF audits, it is stated by PT Asuransi Jiwa X's Internal Audit Supervisor.

\section{Application Analysis}

As stated in the Rules and Circulars it is required to operate in accordance with the rules. The following is an explanation of the application of these five pillars to PT X Life Insurance.

\section{Active Oversight}

PT Asuransi Jiwa $X$ has run the regulation that refers to POJK number 12 in 2017 and is effective on September 19, 2017. From the interviews with the AML and CTF Manager explained that the Directors are aware of this regulation, and has been running effectively and PT Asuransi Jiwa $\mathrm{X}$ already have a special work unit.

\section{CDD Implementation}

In the identification process, PT Asuransi Jiwa $\mathrm{X}$ requests information and supporting documents from prospective customers. One that must be completed by prospective customers is the source of funds for the transaction to originate. The source of funds is very important because to avoid these funds coming from illegal actions. CDD implementation at PT Asuransi Jiwa X explained by the AML and CTF Managers that the process of identifying prospective customers and customers who carry out financial transactions of $\mathrm{Rp}$ $100,000,000$ will be asked for information in the form of a place of residence, address, employment, source of funds, and average income. how flat, and all must be supported by supporting ID identity documents other than KTP or productivity or other supporting identities such as SIM and further analysis of financial transactions will have indications such as conducting structuring or smurfing and if there are suspicious financial transactions will be made into STR and reported to PPATK. The Head of Operations of PT Asuransi Jiwa X explained that the CDD process in the process of accepting new customers is first screened by the Operations team by checking negative news or risk profiles, looking at business occupations, and looking at the income and risk profile scoring already in the system algorithm. The system can identify risks to its customers.

\section{Risk Based Approach}

According to the Operational Team explaining the criteria of risky customers following the PPATK regulations, risky customers are PEPs whose work is a Notary, a civil servant. From interviews with AML and CTF Managers, if the customer is a PEP, the transaction patterns will be seen after becoming a corporate customer and the company has a PEP list or uses third party data but does not yet have an official PEP list issued by the agency that should issue the data and the amount policyholders who have a PEP profile of 34 people.

\section{Enhanced Due Diligence}

From interviews with AML and CTF managers, the company already has a system that can identify these risks and explain that there is no different treatment between prospective customers who are willing to PEP or Non-PEP who want to conduct business relations with the company and will monitor their transaction patterns while they are still naturally there is no suspicion for money laundering. The Head of Operations of PT Asuransi Jiwa X explained that if there were suspicious financial transactions an escalation would be carried out to the next team so that the next team saw the potential for money laundering.

\section{Human Resources}

Based on research on the policies and procedures of PT Asuransi Jiwa X, employee screening has been applied in accordance with regulations by filling out forms regarding background, supporting documents $\mathrm{CV}, \mathrm{BI}$ checking, and using a screening system that is already owned by PT Asuransi Jiwa X. Head of Operations of PT Asuransi Jiwa X explained that training has been given by Legal to employees regularly once a year and uses e-learning.

\section{Obstacles}

Based on the results of the study, one of the obstacles is that the policies and procedures that have not been ratified refer to POJK Number 23 of 2019 and because the regulations were still issued by the Financial Services Authority on September 18, 2019, so PT Asuransi Jiwa $X$ needed time to implement the POJK.

The next obstacle is that PT Asuransi Jiwa X still uses the PEP list obtained from third party data because there is no official PEP list yet to be issued.

The next obstacle is that a special audit is needed to optimize the policies and procedures that have been applied to PT Asuransi Jiwa $\mathrm{X}$ so as to minimize the potential risks faced and to detect weaknesses.

\section{CONCLUSIONS AND RECOMENDATIONS CONCLUSIONS}

PT Asuransi Jiwa $\mathrm{X}$ already has and implements policies and procedures that refer to POJK number 12 of 2017[5]. Supervision conducted by the Directors is very effective and the company has a special work unit. Already monitoring and updating customers, reporting STR, having a list of terrorists and all new and existing employees have attended AML and CFT training. The application of the PT Asuransi Jiwa 
$\mathrm{X}$ CDD process has been carried out. Internal factors, among other things, need to be specifically audited and there is no official PEP list yet.

\section{RECOMENDATIONS}

Policy and procedure reviews must be reviewed immediately and endorsed to be optimal and special audits and monitoring can be carried out. Can do this by comparing with new regulations. Furthermore, you can dig deeper interviews to produce a more optimal analysis.

\section{REFERENCES}

1. Jensen, M. C., \& Meckling, W. H. (1976). Theory of the firm: Managerial behavior, agency costs and ownership structure. Journal of financial economics, 3(4), 305-360.

2. Ujiyantho, M. A., \& Pramuka, B. A. (2007).
Mekanisme corporate governance, manajemen laba dan kinerja keuangan. Simposium Nasional Akuntansi X, 10(6), 1-26.

3. Theodorus, M. T. (2015). Audit Berbasis ISA (International Standards on Auditing). Jakarta: Salemba Empat.

4. Otoritas Jasa Keuangan. 2017. Surat Edaran Otoritas Jasa Keuangan No. 37/SEOJK.05/2017 tentang Pedoman Penerapan Program Anti Pencucian Uang dan Pencegahan Pendanaan Terorisme Di Sektor Industri Keuangan Non-Bank.

5. Otoritas Jasa Keuangan. 2017. Peraturan Otoritas Jasa Keuangan No. 12/POJK.01/2017 tentang Penerapan Program Anti Pencucian Uang dan Pencegahan Pendanaan Terorisme Di Sektor Jasa Keuangan. 